\title{
Evolution of Hungarian security policy thinking in 1989-1999, with a special view on the Hungarian Defence Forces
}

\author{
NÉMETH József Lajos ${ }^{1}$
}

\begin{abstract}
Hungarian security policy thinking has gone through basic and crucial changes in the past two decades. As a result, we can see a kind of "evolution", which began from a former Soviet satellite status and continued through a role seeking period to active membership in the Euro-Atlantic community. One of the most significant security and defence policy changes can be seen with regard to the shaping and restructuring of the Hungarian Defence Forces.

This paper seeks to explain this evolution in the period of 1989-1999 with the support of the János Bolyai Scholarship awarded by the Hungarian Academy of Sciences.
\end{abstract}

Keywords: Hungary, security policy, armed forces, regime change, Warsaw Pact, NATO

\section{Introduction}

Nowadays Hungary has an all-volunteer force, which has to fulfil three fundamental tasks based on the Basic Law (see: Constitution):

- to defend Hungarian territory in case of any aggression;

- to fulfil the tasks deriving from the different collective security (United Nations - UN), collective defence (North Atlantic Treaty Organization - NATO), complex (Europe- an Union - EU), cooperative security (Organisation for Security and Cooperation in Europe - OSCE) and other (for example Visegrad Four/Group - V4) international memberships;

- to participate in "other tasks", which are basically disaster management operations. [1] In other words, the

Hungarian Defence Forces (HDF) has to fulfil peace operations and collective defence operations (based on the NATO Washington Treaty, Article 5).

In order to fulfil the international tasks Hungary sets the level of ambition at 1000 military personnel, which is provided by relatively small manpower (around 29,700 persons in 2012). [2: 2] Today the Hungarian service-members serve on three continents as peacekeepers, mil- itary observers, advisors, trainers or in crisis response operations. Of course, the Hungarian national military representatives are working in administrative positions in NATO and the EU, and they are fulfilling many military diplomatic tasks as well.

The HDF operates under the political guidance and democratic control of the Ministry of

Defence. The operational units are under the command of the so called "Joint Operational

1 email: nemeth.jozsef@uni-nke.hu 
Command" which commands and controls combat, combat-support and combat service support organizational elements of both two Services: the Army and the Air Force.

Based on the above described short "snap-shot" we may raise the question: which are the steps that led to the current situation? In other words, what kind of changes, obstacles and influencing factors formed the Hungarian Defence Forces in the past, for more than two decades, especially until Hungary became a NATO member in 1999?

\section{The Hungarian Armed Forces in the Warsaw Treaty Organization of Friendship, Cooperation, and Mutual Assistance (Warsaw Pact) era}

The history of the Hungarian Armed Forces is very similar to other Eastern and Central Eu- ropean countries after WWII: they became heavily influenced by the Soviets. The Socialist countries led by the Soviet Union established the Warsaw Treaty Organization of Friendship, Cooperation, and Mutual Assistance (Warsaw Pact, WP) in 1955, which gave the political and military framework and content for each member country regarding security issues. The so called "Military Policy" (in the WP it was called Military Doctrine) started to evolve on both sides, based on the fact that in this era nuclear weapons centred military might. There was a strong fear of the final devastating clash (Nuclear World War) which helped shape the political, economic policies or even daily basic life. ${ }^{2}$

During these times Hungary was suffering under Soviet suppression which resulted in a short and dramatic revolution in 1956, in which the Hungarian Military played a crucial role via supporting the freedom fighters. It was a clear and dramatic message to the Soviets and therefore it was not a surprise when the Hungarian Communist government reshaped and reorganized many things in Hungary, including the Hungarian People's Army. As a result Kádár János, the General Secretary of The Hungarian Socialist Workers Party, stated in 1958 at a military conference that "the Central Committee of the Hungarian Communist Party trusts the People's Army". [3: 83]

When the Warsaw Pact started to function it did not appear, that there would be so many tensions among the partners. One of the possible reasons for that lay in the centralized, Mos- cow led politico-military directives, which — at least theoretically — had to be accepted and executed by each member state. But the problem with this "guidance" was that it was "too large" for the WP Member states who were supposed to meet all of the Soviet military expec- tations, especially those which were included in to the Five Years Armament Modernization Plan (sometimes with expectations of full rearmament and military modernization)(!). Hun- gary, for instance, tried to use every opportunity to oppose, or at least to reduce the heavy military investment pressure arriving from the Soviet — imperial level minded — party politicians and generals. [4: 51-112]

As time passed, the ' 80 s brought many changes in international relations: the détente experienced in the ' 70 s had disappeared and many internal and external tensions started to boil on both sides. By these years the Hungarian People's Army reached the level and char- acteristics of a "mass army": too high peacetime strength; using obsolete and new military

2 At this point it is important to add, that the term "military policy" in the Soviet (Eastern) military sciences was similar to the term "defence policy" used by Western scholars. Later this term (military policy) almost disappeared and nowadays the term "defence policy" is the closest to the original meaning. 
equipment at the same time; it spent large amounts on weapon systems, materiel and service- members because the country had to follow WP (the Soviet) military doctrine; and seasonal tasks to support the national economy. [5: 6]

The high level military spending put a lot of pressure on the already suffering Hungarian economy and as a result the Hungarian Socialist Workers' Party decided to launch a military reform in order to build a more adequate military force based on the economic realities, the country's geographical location, the "real" role of Hungary in the Warsaw Pact and the quick and crucial changes that had happened in military technology. [5]

The reorganization of the Hungarian People's Army — under code name "RUBIN" - came into force on the $1{ }^{\text {st }}$ of March 1987, and the division-regiment structure was replaced by brigade organizations commanded directly by the Army HQs. The new unit structure was different from the existing Soviet military structure, who expressed their revulsion but they did not prohibit it. At this moment it is crucial to mention that this "peaceful" approach was related more to the Gorbachev launched politics called "glasnost" and "perestroika", than to the "kindness" of the Soviet generals. In the second part of the 80's we could see a series of national decisions, they were supposed to provide some relief and some change some special characteristics of the Hungarian Armed Forces (for example: national tricolour on the Buda Castle, changes in the uniforms and daily official greetings, etc.).

This "openness" led also to the breakthrough in 1989, when the Warsaw Pact forces start- ed sharing openly their force's strength: in the case of Hungary the Armed Forces consisted of 155,700 persons (including civilians) in peace time. [5: 8] In January 1989 — as a result of the changes in contemporary international relations — it was announced that the Hungarian People's Army would undergo a reduction through 1989-1990 by 9\%. [5: 9] The changes were supposed to be executed in three steps: the first to be made at the end of 1989, when the political-governmental and the command and control tasks of the Ministry of Defence (MoD) were separated: a small civilian Ministry of Defence was designed for the political functions and the direct command and control of the Forces was given to the independent Command of the Hungarian People's Army led by the Commander of the Forces.

The second step was overridden by many unexpected international and social changes, because in November 1989 Prime Minister Németh Miklós declared more radical cuts in the force structure beyond the earlier planned $9 \%$. The new reform goals were more: $20-25 \%$ cuts in manpower and the transforming of the Hungarian Military into a new, nationdefend- ing role. [5: 11] However, some experts argued that his step was more related to the expec- tations that the armed forces needed to compare to the neighbouring countries. The political decision was more "driven" by the upcoming, democratic elections (1990) and it served to support the Communist Party's political campaign efforts. [6: 2] If this is true, we can pose the question: where did the trust expressed by Janos Kadar in 1956 of the Hungarian People's Army go by the end of the 80 's?

The end of the 80's was a very intensive and historical period for the Hungarian Military:

- it was necessary to solve the question of the Soviet nuclear weapons stationed in the Bakony mountains;

- Hungarian political leaders initiated the Soviet troop withdrawal which ended at the end of June 1991;

- the Hungarian Armed Forces gave assistance and support to the refugees escaping from Ceausescu-led Romania; 
- at a domestically and internationally crucial moment — in May-June 1989 — Hunga- ry lifted the so called "Iron Curtain" at her western border, and in September opened it to many Eastern-German citizens, which basically gave a huge boost to the upcoming changes, such as the collapse of the Berlin Wall (November 1989).

Meanwhile significant changes were taking place in Hungarian society too: the so called "Roundtable Talks" started to evolve and created a semi-half democratic sphere; on $23^{\text {rd }}$ of October 1989 Hungary became a "Republic" and on $1^{\text {st }}$ of March 1990, the Hungarian Peo- ple's Army got back its old name: "Hungarian Defence Forces" (Magyar Honvédség). [5: 9] As we look back to this year, we can have a sense of "euphoria", but we should not forget that the Soviet Union and the Warsaw Pact still existed at that time...

\section{New political system, new defence forces}

The democratic transition in Hungary had a similar character to the Polish one, it was "a tran- sition through extrication", because although the leading regime participated in the system change negotiations, it did not have a decisive role in it. Everything happened differently for instance in Romania when the former communist power did not play a progressive role and the changes there are named "transition through transaction". [6:1]

In the spring of 1990 the first democratic elections happened in Hungary after the com- munist system collapsed. As a result, the six parties in Parliament, started to build the ele- ments of a liberal democracy (rule of law, freedom, market economy, etc.). The new govern- ing party — the Hungarian Democratic Forum (Magyar Demokrata Fórum — MDF) - gave strategic importance to the Ministry of Defence. Für Lajos was the first appointed civilian defence minister. [7: 138]

Parallel, to the internal political changes, the new government used every effort to aban- don the Warsaw Pact, and some Hungarian experts argued, that it had to be eliminated by inner efforts not by jumping out. [8: 133] Finally, the WP formally ended on the $1^{\text {st }}$ July 1991, but this decision was made earlier at the Political Consultative Meeting in Budapest on $25^{\text {th }}$ of February 1991. [9: 6]

At this moment, the Hungarian Defence Forces became a really national and independent entity, which — at the same time - had to face very serious external and internal challenges. Based on the latest findings and research, it seems that when the Warsaw Pact was disband- ed, not only did a military alliance disappear, but also the support, maintenance and military industry too: as a result, many people lost their jobs and the national economies suffered heavy losses.

After these changes Hungary suddenly became alone and when the earlier security um- brella disappeared a so called "security vacuum" was generated. In this situation the country had to decide how to provide the necessary security and defence for the country. The Hun- garian politicians, civilian and military strategists faced the fact that the earlier allies became independent too, and the former commonly shared interests turned out to be not so commonly shared or in fact even opposing. Not only bilateral relations required a new beginning, but Hungary's future foreign policy priorities which were under huge debate and many times became part of daily political debates — had to be formulated. Basically, in the years of 1989-1991 there were six possible foreign policy options:

- neutrality; 
- full independence;

- regional cooperation;

- joining the European security system;

- Euro-Atlantic integration; [10]

- to continue the cooperation with the Soviet Union in a more flexible framework (but this idea was quickly dropped recognizing the international and domestic reality). [11: 12]

As we can see, in all of the above mentioned scenarios the Hungarian Defence Forces should have played a crucial role, but in the finally selected version the Euro-Atlantic in-tegration represented a huge challenge for the HDF. We should not forget that at that time the Hungarian military was still oversized, overloaded, not functioning effectively, socially under-supported and struggling with serious financial problems.

In June 1991 Slovenia — after the declaration of its independence — was attacked by the Yugoslavian forces and after this so called "10 day war" the Balkan Wars started in Croatia, Bosnia and Herzegovina, and Serbia until 1995.

Because many of these former Yugoslavian states were direct neighbours of Hungary, the Hungarian Defence Forces had to face a serious challenge: not just to secure the homeland territory but at the same time to avoid any escalation into fighting.

Under these circumstances it became more and more clear that basically four parallel external tasks should be fulfilled by the Hungarian Defence Forces:

- to establish and maintain an independent homeland defence system;

- to meet the new security and defence requirements stemming from the Euro-Atlantic integration;

- to participate in the process of conventional weapons reduction in Europe;

- to give adequate answers to the regional security challenges (including the neighbouring states, NATO, the collapse of the Soviet Union, the Balkan Wars, etc.). [9: 8]

Of course, these tasks could not be fulfilled without a strong and legitimate legal back- ground, which was laid down in the New Constitution (1989), the Law on Homeland De- fence (1993/CX) the Basic Security Policy Principles (March, 1993) and the Basic Homeland Defence Principles (April, 1993). Additionally, the Government Programme which was accepted in September 1990 - gave some important guidelines related to the upcoming defence restructuring tasks.

One of the most remarkable changes of the Hungarian Defence Forces was visible in manpower reduction, which is shown in the following table:

Table 1. Manpower reduction in the Hungarian Defence Forces between 1989 and 1993

Source: [5: 26]

\begin{tabular}{|l|c|c|c|c|c|}
\hline Year & $\mathbf{1 9 8 9}$ & $\mathbf{1 9 9 0}$ & $\mathbf{1 9 9 1}$ & $\mathbf{1 9 9 2}$ & $\mathbf{1 9 9 3}$ \\
\hline Manpower & 155,700 & 143,200 & 121,000 & 104,000 & 100,000 \\
\hline $\begin{array}{l}\text { Reduction related } \\
\text { to 1989 }\end{array}$ & - & $8 \%$ & $22 \%$ & $33 \%$ & $36 \%$ \\
\hline
\end{tabular}


As we can see the level of manpower reduction by 1993 was $36 \%$ related to the size of the Hungarian Armed Forces in 1989. The most dramatic change took place in the number of the conscripts: their number dropped by $43 \%$ (from 91,900 in 1989 to 52,340 by 1993). [5: 26]

Military spending was the following between 1989-1994:

Table 2. Military spending in Hungary in GDP\% between 1989 and 1993.

Source: World Bank ${ }^{3}$

\begin{tabular}{|l|c|c|c|c|c|}
\hline Year & $\mathbf{1 9 8 9}$ & $\mathbf{1 9 9 0}$ & $\mathbf{1 9 9 1}$ & $\mathbf{1 9 9 2}$ & $\mathbf{1 9 9 3}$ \\
\hline GDP\% & 3.8 & 3.1 & 2.4 & 2.3 & 2.1 \\
\hline
\end{tabular}

As we can see the defence budget was also decreasing very dramatically between 19901991.

During the first democratic governmental period (1990-1994) the internal changes in the

HDF affected the following fields:

- organization, structure and dislocation;

- the direction of training: from offensive operations to active defence;

- de-politicizing the Military and strengthening national characteristics;

- introducing new military capabilities/components (such as an airborne battalion, an electronic warfare capable regiment);

- struggling with the decreasing quality of military equipment;

- growing morale problems due to the continuous restructuring efforts;

- creating the elements of human resources;

- growing activity in military diplomacy;

- reshaping the military educational system;

- execution of the tasks stemming from the international crisis response and peace- keeping operations (such as in the First Gulf War - 1991; operations in the Balkans; etc.);

- struggling for adequate social support;

- creating new military elements in order to fulfil the constitutional requirement related to the freedom of conscience;

- building the advocate system for military personnel;

- creating and adjusting to democratic control.

\section{Developments in 1994-1998}

After the spring elections in 1994, the Hungarian Socialist Party gained a majority in the Hungarian Parliament. The old-new socialist leadership (the government was led by Prime Minister Horn Gyula) basically continued the earlier integration procedure into the Euro- Atlantic security system. Its main and central goal was to join the North-Atlantic Treaty Organization (NATO). The first step was taken already in 1991, when the North-Atlantic Cooperation Council was created "as a forum for dialogue and cooperation with NATO's former Warsaw Pact adversaries" and Hungary became its member. [12]

3 data.worldbank.org/indicator/MS.MIL.XPND.GD.ZS?page=4, (downloaded: 2704 2013) 
In February 1994 Hungary — among many other countries — signed the framework con- tract of the Partnership for Peace Programme issued by the Heads of States and Governments at the Meeting of the North Atlantic Council on 10-11 January 1994. [13] This step, from one side, made it possible for the HDF to take a look at how the Alliance is working and what the basic requirements are, from the other side, it helped to strengthen regional security. This last effect was extremely important, especially taking into consideration, that in the surrounding countries many changes happened in those years, for example, the number of Hungary's neighbouring countries raised from five to seven.

In spring 1995 Hungary started to participate in the Planning and Review Process (PARP), the goal of which "is to provide a structured basis for identifying partner forces and capabil- ities that could be available to the Alliance for multinational training, exercises and opera- tions". [14]

On 29 January 1996 Hungary expressed its desire to join NATO and after more than one year and a series of different professional talks NATO invited the Czech Republic, Poland and Hungary to become full members at the Madrid Summit in 1997. In order to strength- en the national desire and get strong public support a referendum was held on $16^{\text {th }}$ of No- vember 1997 . Voter participation was $49 \%$, and $85.33 \%$ of them supported NATO member- ship. [5: 45]

Finally, on the $4^{\text {th }}$ of April 1999, Hungary together with the Czech Republic and Poland, signed the documents of accession to NATO in a ceremony in Independence, Missouri, Unit- ed States, that marked their formal entry into the Alliance.

At this point it is important to mention, that parallel to the above mentioned process many integration steps were made toward to the European Union (EU) too, and Hungary became an EU member in 2004.

During these years, the HDF had to learn, understand and apply the term "compatibility", in order to prove its ability and creditability as a NATO candidate member. At the same time NATO also wanted to get evidence regarding the development of the Hungarian Defence Forces in meeting the minimum military requirements.

In 1995 the Alliance adopted a Study on NATO Enlargement in order to give and get the necessary information about the enlargement process to all participants. [15] This study contained many important questions and requirements, however the financial cost of acces- sion remained unknown. Notwithstanding, since 1997, defence spending has started to grow again: for the first time after the communist system had collapsed. [11: 22]

The tasks mentioned for the first governmental period on the one hand became more sophisticated (such as the legal background, military diplomacy, restructuring the command and control elements, etc.) and on the other hand new elements evolved such as the active participation in the peaceful solution of the Balkan crisis. This included many different ef- forts:

- sending troops to the Implementation Force (IFOR) and afterwards to the Stabilization Force (SFOR) in 1995-1998;

- providing host nation support (for example at the airbase of Taszár);

- participating in the Partnership for Peace (PfP) exercises (for example providing engineer support in Okučani). 
Parallel to the above mentioned changes the manpower reduction of the HDF continued:

Table 3. Manpower reduction in the Hungarian Defence Forces between 1994 and 1998.

Source: [16: 79]

\begin{tabular}{|l|c|c|c|c|c|}
\hline Year & $\mathbf{1 9 9 4}$ & $\mathbf{1 9 9 5}$ & $\mathbf{1 9 9 6}$ & $\mathbf{1 9 9 7}$ & $\mathbf{1 9 9 8}$ \\
\hline Manpower & 99,248 & 81,266 & 66,872 & 60,000 & $61,500^{4}$ \\
\hline
\end{tabular}

Military spending showed the same reduction as in the earlier governmental period, but in 1997 and 1999 we could see some growth, which was related to the upcoming NATO integration.

Table 4. Military spending in Hungary in GDP\% between 1994 and 1999.

Source: World Bank ${ }^{5}$

\begin{tabular}{|l|c|c|c|c|c|c|}
\hline Year & $\mathbf{1 9 9 4}$ & $\mathbf{1 9 9 5}$ & $\mathbf{1 9 9 6}$ & $\mathbf{1 9 9 7}$ & $\mathbf{1 9 9 8}$ & $\mathbf{1 9 9 9}$ \\
\hline GDP\% & 2.0 & 1.6 & 1.5 & 1.7 & 1.5 & 1.7 \\
\hline
\end{tabular}

An interesting and very remarkable solution happened in the HDF's training and educa- tion system, when the Zrínyi Miklós National Defence University (ZMNDU) was established from the previous independent military institutions in 1996, following the US example in Washington DC, that is to say the National Defence University concept. The new university started to educate civilian and military students together in 1997 in order to get "experts on security and defence policy" after a five year study period. ${ }^{6}$

\section{Conclusions}

It is still debated how well the Hungarian Defence Forces was restructured, reshaped or re- edified in the years of the 90s. It is a fact, however, that so many changes occurred in the pe- riod of 1989-1999 that it greatly changed the basis of the Hungarian Military. Without these changes we would not have been able to create that modern HDF which we have nowadays During the analysed period the international security framework changed dramatically and deeply influenced Hungarian security and defence policy thinking. As one of the results, the HDF changed its former Eastern-Western operating directions into a nation-character- ized and NATO compatible force.

4 Accepted by the Parliament Resolution of 1997/124 (XII.18.)

5 data.worldbank.org/indicator/MS.MIL.XPND.GD.ZS?page=3, (downloaded: 2704 2013)

6 This branch still exists in the framework of the National University of Public Service (NUPS), Budapest. 
NÉMETH József Lajos: Evolution of Hungarian security policy thinking in 1989-1999, with a special view...

\section{References}

[1] Magyarország Alaptörvénye. (Basic Law of Hungary.) 2504 2010, Article 45

[2] KISS Z. L.: A Honvéd Vezérkar fönök elöadása a Nemzeti Közszolgálati Egyetem biztonság-és védelempolitika szakos hallgatóinak. (Speech given by the Hungarian Chief of the General Staff for the students of the National University of Public Service.) 2505

2012. www.honvedelem.hu/container/files/attachments/32119/vezerkarfonoki_eloadas_ nke_2012_0525.pdf, (downloaded: 1205 2013)

[3] KÁDÁR J.: Béke, függetlenség, honvédelem. (Peace, Independence, Homeland Defence.) Budapest: Zrínyi Katonai Kiadó, 1985.

[4] KÁRPÁTI F.: Puskalövés nélkül. (Without Firing Shots.) Budapest: Duna International Kft., 2011.

[5] SZÁNTÓ M.: A Magyar Honvédség a rendszerváltástól a NATO-tagságig, 1989-1999. (The Hungarian Defence Forces: from the political changes to the NATO membership, 1989-1999.) Budapest: Zrínyi Miklós Nemzetvédelmi Egyetem, 2002.

[6] SIMON, J.: NATO and Hungary: Problems in Civil-Military Relations. Oxford: Rowman and Littlefield Publishers Inc., 2003.

[7] CSENDES L.: Hadseregtörténet. (History of the Hungarian Forces.) Új Honvédségi Szemle, Különkiadás (1998).

[8] NÉMETH J. L.: Irányított interjú Deák Péterrel az MTA Bolyai János Kutatói Ösztöndíj támogatásával. (Interview with Deák Péter.) Hadtudományi Szemle, VI 1 (2013).

[9] MAKK L.: A haderő átalakitása a hidegháború utáni korszak biztonsági kihívásainak tükrében. (Shaping the Hungarian Defence Forces in light of the new Security Challenges of the Post-Cold War Period.) Budapest: Zrínyi Miklós Nemzetvédelmi Egyetem, 2008.

[10] A kilencvenes évek eleje. (The beginning of the '90s.) biztpol.corvinusembassy. com/?module=corvinak\&module_id=4\&cid=119, (downloaded: 2004 2013)

[11] SZENES Z., TÁLAS P. (Eds.): Tíz éve a NATO-ban. (Ten years in NATO.) Budapest: Zrínyi Kiadó, 2009.

[12] The North Atlantic Cooperation Council (NACC) (archived). www.nato.int/cps/en/natolive/ topics_69344.htm (downloaded: 2504 2013)

[13] Partnership for Peace: Framework Document. Ministerial Meeting of the North Atlantic Council/North Atlantic Cooperation Council. Brussels: NATO Headquarters, 10-11 01 1994. www.nato.int/docu/comm/4995/c940110b.htm (downloaded: 2504 2013)

[14] Partnership for Peace Planning and Review Process. www.nato.int/cps/en/natolive/ topics_68277.htm (downloaded: 2704 2013)

[15] NATO: Study on NATO Enlargement. 3 September 1995. www.nato.int/cps/en/natolive/ official_texts_24733.htm(downloaded: 2504 2013)

[16] MÉSZÁROS K. (Ed.): A honvédelem négy éve: 1994-1998. (Four Years of National Defence: 1994-1998.) Budapest: Zrínyi Kiadó, 1998. 